\title{
Implications of Different Cancer Stem Cell Phenotypes in Breast Cancer
}

\author{
ARNAUD DA CRUZ PAULA ${ }^{1,2}$ and CARLOS LOPES ${ }^{1,2}$ \\ ${ }^{1}$ Pathology and Molecular Immunology Department, Abel Salazar Institute of Biomedical Sciences, Porto, Portugal; \\ ${ }^{2}$ Department of Pathology, Portuguese Oncology Institute, Porto, Portugal
}

\begin{abstract}
The attempts to identify, isolate and characterize cancer stem cell populations are mostly dependent on cellsurface markers. In breast cancer, several putative breast cancer stem cell (BCSC) markers have already been reported, but the agreement on their phenotypic characterization is still absent. In fact, it became unfeasible to obtain a universal combination of markers that could specifically identify BCSCs in all cases of breast cancer. Breast cancer heterogeneity as reflected by various histological subtypes, with variable clinical presentations and diverse molecular signatures also contributes to major drawbacks. Indeed, intra-tumor heterogeneity leads to a single tumor to contain, at any given time, tumor cell populations displaying different molecular profiles and biological properties. As a consequence, several BCSC phenotypes were described, with some being associated with aggressive forms of breast cancer. Although the validation of the CSC model remains an ongoing task, it is important to define which BCSC phenotypes have high tumorigenic potential and ability to resist therapeutic agents. For this reason, a concise review is presented here regarding the implications of the most studied BCSC markers and phenotypes in breast cancer progression and treatment.
\end{abstract}

In the last two decades, breast cancer research has majorly focused on the identification, isolation and characterization of breast cancer stem cells (BCSCs). In order to do so, some

This article is freely accessible online.

Correspondence to: Arnaud Da Cruz Paula/Carlos Lopes, Pathology and Molecular Immunology Department, Abel Salazar Institute of Biomedical Sciences, Jorge Viterbo Ferreira Street, $n^{\circ} 288$, 4050-313, Porto, Portugal. Tel: +351 967693532, +351 917270209, Fax: +351 225511184, e-mail: arnaudcpaula@hotmail.com/calopes@icbas.up.pt

Key Words: Breast cancer, breast cancer stem cell markers, CD24, CD44, ALDH1, CD133, integrins, review. genes with stem cell properties were studied and their corresponding proteins were subsequently validated as markers of $\operatorname{BCSC}(1,2)$. As a consequence, a plethora of studies have been published describing the impact of BCSCs identified by these established markers, such as hyaluronan receptor (CD44), signal transducer CD24 (CD24) and aldehyde dehydrogenase1 (ALDH1), as tumor-initiating cells in breast cancer progression with high propensity to metastasize and to be resistant to therapeutic treatments (2-4). With the increasing evidence for such ability, researchers have attempted to demonstrate which altered genes or dysregulated gene signaling pathways potentially contribute for the tumorigenic potential of BCSCs. In fact, $\mathrm{NOTCH}, \mathrm{WNT} / \beta$-catenin, or Hedgehog signaling pathways were shown to be deregulated in subpopulations of these cells $(5,6)$. With evidence forthcoming regarding the effects of the stroma and the microenvironment in breast tumor progression, several genes have also been reported to be associated with BCSCs (7). The phenomenon of epithelial-mesenchymal transition (EMT) and mesenchymal-epithelial transition in breast cancer cells during tumor progression was also an important discovery. Such dynamic transitions were demonstrated in BCSCs as an explanation for their ability to invade and to colonize other parts of the body, which has indeed questioned some of the tenets of the CSC model (8). With all this knowledge, targeting BCSCs for breast cancer treatment was demanded and currently, some important inhibitors targeting subpopulations of BCSCs or gene signaling pathways that regulate these subpopulations are reported to be strongly effective $(9,10)$.

One concern has, however, changed the definition of BCSCs: breast cancer heterogeneity (11). Due to the observations that not all BCSC markers are expressed in all breast cancer subtypes, research for different BCSC markers and different combinations of these markers that could be restricted to a specific breast cancer subtype or associated with aggressive forms of this disease is ongoing $(12,13)$. As a consequence, different BCSC phenotypes have been described and characterized, and in the future, other 
molecules will be reported to have stem cell properties. Beyond the tenets of the CSC model, it is important to define which BCSC phenotypes have high tumorigenic potential and also great ability to resist therapeutic agents (14). Moreover, it is also crucial to determine which oncogenes or tumor-suppressor genes, other than those already described, are consistently mutated within these phenotypes being able to drive tumorigenesis.

In invasive breast cancer (IBC), several markers have been immunohistochemically characterized showing that the prevalence of stem cell-like and more differentiated markers varies according to tumor subtype and histological stage (15). For this reason, a concise review is presented here regarding the implications of the most studied markers of BCSCs and phenotypes in breast cancer progression and treatment, as well as a description of promising inhibitors able to target these cells.

\section{$\mathrm{CD} 44^{+} / \mathrm{CD}^{-/ \text {low }}{ }^{\text {Phenotype }}$}

The combination of the BCSC markers CD44 and CD24 is by far the most extensively studied and undeniably the most contentious. The pioneering study by Al-Hajj et al. showed that as few as $100 \mathrm{CD} 44^{+} / \mathrm{CD} 24^{-/ \text {low }}$ cells in patients with breast cancer were able to form tumors in mice, whereas tens of thousands of cells with alternative phenotypes failed to do so (1).

Immunohistochemically, breast cancer tissues were investigated for the prevalence of $\mathrm{CD} 44^{+} / \mathrm{CD} 24^{-/ \text {low }}$ tumor cells and their prognostic value. In a study including 136 patients with and without recurrence, the prevalence of CD $44^{+} / \mathrm{CD} 24^{-/ \text {low }}$ cells was $\leq 10 \%$ in $78 \%$ of cases and $>10 \%$ in the other $22 \%$. However, no significant correlation between the prevalence of this phenotype and tumor progression was noted nor were significant differences seen in recurrence, disease-free (DFS) or overall (OS) survival (16). In another study of 95 patients with IBC subjected to mastectomy, radiotherapy, chemotherapy and axillary lymph node dissection, $\mathrm{CD} 44^{+} / \mathrm{CD} 24^{-/ \text {low }}$ cancer cells were shown to be abundant in the basal subgroups and absent from those with human epidermal growth factor type 2 (HER2)-positive tumors (17). This phenotype was also associated with breast cancer 1 (BRCAl) mutational status, which was correlated with basallike tumor status, and despite its association with increased poor prognostic features, it was not able to predict OS (18). Regarding such important studies, the $\mathrm{CD} 44^{+} / \mathrm{CD} 24^{-/ \text {low }}$ phenotype has not a distinct prognostic value but it seems to be enriched in those with basal-like breast cancer subtype.

Gene-expression profiling of $\mathrm{CD} 44^{+} / \mathrm{CD} 24^{-/ \text {low }}$ breast cancer cells revealed a signature of 186 genes associated with invasion and poor prognosis $(19,20)$. This signature was enriched in genes related to the cell cycle, calcium-ion binding, chemotaxis, differentiation, protein transport, signal transduction and ubiquitination. Among these genes, this phenotype was observed to express high levels of interleukin-1 alpha (IL1 $\alpha$ ), IL6, IL $\beta$ and urokinase plasminogen activator (uPA), which predispose to distant metastases (Table I).

The enrichment of $\mathrm{CD} 44^{+} / \mathrm{CD} 24^{-/ \mathrm{low}}$ cells demonstrated in primary breast tumors following radiation and chemotherapy has suggested an innate resistance to standard treatments (4). The presence of ATP-binding cassette transporters (which confer resistance to chemotherapeutic agents) highly expressed in a subpopulation of CSCs with these markers led to such assumption $(21,22)$. In fact, the ability of these cells to replicate in an in vitro model following at least four generations of xenograft transplanted mice has also suggested their significant role in tumor relapse and metastasis (23). Potential mechanisms of chemotherapy and radiation resistance associated with this phenotype were shown to include the presence of lower concentration of reactive oxygen species, cell dormancy, efficient DNA-repair mechanisms, overexpression of EMT markers, and activation of WNT/ $\beta$-catenin, Hedgehog and NOTCH signaling pathways and signal transducer and activator of transcription 1 (STAT1) and STAT3 signaling $(5,24,25-30)$. As a consequence, the $\mathrm{CD} 44^{+} / \mathrm{CD} 24^{-/ \text {low }}$ phenotype in breast cancer is currently being assessed as a therapeutic target.

One of the most promising therapeutic agents, MK0752, belongs to the class of $\gamma$-secretase inhibitors and was recently administered to patient-derived tumor xenograft in combination with docetaxel. This inhibitor was reported to improve docetaxel activity, leading to a decrease of $\mathrm{CD} 44^{+} / \mathrm{CD} 24^{-/ \text {low }}$ tumor cells, reduce mammosphereforming activity, consequently leading to the inhibition of tumor formation after serial transplantations (9). With these results, a phase I clinical trial in patients with advanced breast cancer that did not respond to standard treatments was developed, culminating in a decrease of $\mathrm{CD} 44^{+} / \mathrm{CD} 24^{-/ \text {low }}$ tumor cells and in the reduction of the tumor bulk (9). This inhibitor is also being tested in combination with endocrine therapy (tamoxifen or letrazole in patients with early-stage breast cancer) and chemotherapy (docetaxel in patients with locally advanced or metastatic breast cancer) (31).

Another inhibitor from the same class, PF-03084014, was also administered in a phase I trial for the treatment of advanced breast cancer and was found to reduce NOTCH activity and to considerably reduce tumor cell migration and mammosphere-forming efficiency (31). Its ability to reduce self-renewal and expression of NOTCH target genes was also demonstrated in in vivo studies (32).

The major promising compound for breast cancer treatment is metformin, a drug generally used for anti-diabetic therapy. Metformin has been shown to preferentially target $\mathrm{CD} 44^{+} / \mathrm{CD} 24^{- \text {low }}$ cell subpopulations in different molecular subtypes of breast cancer cell lines and to have a synergistic 
Da Cruz Paula et al: Phenotypic Heterogeneity of Breast Cancer Stem Cells (Review)

Table I. Characteristics of the different assessed breast cancer stem cell (BCSC) phenotypes and markers.

\begin{tabular}{|c|c|c|c|c|c|}
\hline $\begin{array}{l}\text { BCSC phenotype/ } \\
\text { markers }\end{array}$ & $\begin{array}{l}\text { Tumorigenic } \\
\text { potential }\end{array}$ & $\begin{array}{l}\text { Clinicopathological } \\
\text { features }\end{array}$ & $\begin{array}{c}\text { Functional/mechanistic } \\
\text { observations }\end{array}$ & Clinical observations & Inhibitors \\
\hline $\begin{array}{l}\text { CD } 44^{+/} \\
\text {CD24-llow }\end{array}$ & $\begin{array}{l}\text { Able to drive tumor } \\
\text { formation when } \\
\text { inoculated into } \\
\text { NOD/SCID } \\
\text { mice (1) }\end{array}$ & $\begin{array}{l}\text { Enriched in basal-like } \\
\text { and claudin-low breast } \\
\text { cancer subtypes (17) } \\
\text { Associated with BRCA1 } \\
\text { mutational status (18) } \\
\text { Poor prognosis (16) }\end{array}$ & $\begin{array}{l}\text { Increased expression of IL1 } \alpha \text {, } \\
\text { IL6, IL } \beta \text { and uPA (19), 20), } \\
\text { ABC transporters, STAT1 and } \\
\text { STAT3 }(22,28,29) \text {, TWIST } \\
\text { and SNAI1 }(24,25) \text {, and of } \\
\text { WNT/ } \beta \text {-catenin, Hedgehog } \\
\text { and NOTCH signaling } \\
\text { pathways }(26,31) \\
\text { Low levels of ROS (5) } \\
\text { Associated with cell dormancy } \\
\text { and efficient DNA } \\
\text { repair mechanisms (28) }\end{array}$ & $\begin{array}{l}\text { Tumor recurrence } \\
\qquad(25) \\
\text { Resistance } \\
\text { to radiation } \\
\text { and standard } \\
\text { treatments (4) } \\
\text { High metastatic } \\
\text { propensity (23) }\end{array}$ & $\begin{array}{c}\text { Short hairpin RNAs } \\
\text { (102) } \\
\text { Gamma-secretase } \\
\text { inhibitors }(9,31,32) \\
\text { Metformin }(33,34) \\
\text { ATRA or vorinostat } \\
\text { (103) } \\
\text { Niclosamide (36) } \\
\text { Disulfiram/copper (37) } \\
\text { Cyclophosphamide } \\
\text { (38) }\end{array}$ \\
\hline ALDH1 & $\begin{array}{l}\text { Able to generate a } \\
\text { stable tumor via } \\
\text { orthotopic injection } \\
\text { of ALDH1+ cells into } \\
\text { NOD/SCID mice ( } 2)\end{array}$ & $\begin{array}{l}\text { Associated with poorer } \\
\text { clinical outcomes } \\
\text { including ER } \\
\text { negativity, } \\
\text { basal subtype } \\
\text { and } H E R 2 \\
\text { amplification }(2,42)\end{array}$ & $\begin{array}{c}\text { Increased expression } \\
\text { of Ki-67 and EZH2 } \\
(42,104), \text { HIF- } 1 / 2 \alpha \\
(47), \text { HOXA1 and } \\
\text { MUC4 (49) and of } \\
\text { TGF } \beta 2, \text { NOTCH and } \\
\text { WNT/ } \beta \text {-catenin } \\
\text { signaling pathways } \\
(48,51,105)\end{array}$ & $\begin{array}{c}\text { Tumor recurrence }(15) \\
\text { Enhanced capacity } \\
\text { for metastatic } \\
\text { behavior }(15,52) \\
\text { Resistance to sequential } \\
\text { paclitaxel-and } \\
\text { epirubicin-based } \\
\text { chemotherapy (40) }\end{array}$ & $\begin{array}{c}\text { DEAB (54) } \\
\text { ATRA (54) } \\
\text { Salinomycin (10) } \\
\text { Disulfiram/ } \\
\text { copper (106) }\end{array}$ \\
\hline $\begin{array}{l}\mathrm{CD}_{4} 4^{+/} \\
\mathrm{ALDH}^{+/ \text {high }}\end{array}$ & $\begin{array}{l}\text { Able to drive tumor } \\
\text { formation when } \\
\text { inoculated into } \\
\text { NOD/SCID } \\
\text { mice (14) }\end{array}$ & $\begin{array}{c}\text { Able to identify } \\
\text { high risk patients } \\
\text { in breast cancer (12) } \\
\text { Enriched in high-grade } \\
\text { DCIS (57) }\end{array}$ & $\begin{array}{c}\text { Increased levels of } \\
\text { NOTCH and WNT/ } \\
\beta \text {-catenin signaling } \\
\text { pathways (59) } \\
\text { High levels of } \\
\text { P-glycoprotein, } \\
\text { GSTpi, and CHK1 (54) } \\
\text { Cell dormancy (58) }\end{array}$ & $\begin{array}{c}\text { Predicts distant } \\
\text { metastasis } \\
\text { and OS (58) } \\
\text { High metastatic } \\
\text { propensity (54) } \\
\text { Resistant to standard } \\
\text { cancer therapies (54) }\end{array}$ & $\begin{array}{l}\text { DEAB (54) } \\
\text { ATRA (54) }\end{array}$ \\
\hline CD133 & $\begin{array}{l}\text { Ability to form tumors } \\
\text { in NOD/SCID mice } \\
\text { from BRCA1- } \\
\text { associated breast } \\
\text { cancer cell lines (66) }\end{array}$ & $\begin{array}{l}\text { Enriched in IBC } \\
\text { and particularly in } \\
\text { TNBC (67-69) } \\
\text { CTCs detection } \\
\text { in patients with } \\
\text { TNBC }(70,71)\end{array}$ & $\begin{array}{l}\text { Increased expression } \\
\text { of NOTCH1, } \\
\text { ALDH1, FGFR1 } \\
\text { and SOX1 (66) } \\
\text { High levels of } \\
\text { NANOG, SOX2, and } \\
\text { BMI-1 in CD44+/ } \\
\text { CD49f } \text { f }^{\text {high/CD133/2high }} \\
\text { breast cancer cells (73) }\end{array}$ & $\begin{array}{l}\text { Tumor recurrence (73) } \\
\text { Resistant to standard } \\
\text { cancer therapies (74) }\end{array}$ & $\begin{array}{l}\text { Paclitaxel and } \\
\text { surface antibody } \\
\text { to CD133 (75) }\end{array}$ \\
\hline CD29/CD49f & $\begin{array}{l}\text { Enrichment of CD29 } \\
\text { and CD49 in } \\
\text { combination with } \\
\text { CD24 for cancer- } \\
\text { initiating cells in } \\
\text { primary breast } \\
\text { tumors (79) }\end{array}$ & $\begin{array}{c}\text { CD29 associated } \\
\text { with shorter OS } \\
\text { and DFS }(86,87) \\
\text { CD49f associated with } \\
\text { poor clinical outcomes } \\
\text { and regarded as a } \\
\text { prognostic factor } \\
(88,89)\end{array}$ & $\begin{array}{l}\text { Increased expression of } \\
\text { EMT markers }(82,89) \\
\text { EpCAM }^{+} / \mathrm{CD} 49 \mathrm{f}^{+} \text {breast } \\
\text { cancer cells proposed } \\
\text { to be the cell origin } \\
\text { of BRCA1-associated } \\
\text { basal breast cancer }(90)\end{array}$ & $\begin{array}{l}\text { Tumor relapse } \\
(107,108) \\
\text { High metastatic } \\
\text { propensity }(91) \\
\text { Resistance to } \\
\text { therapy }(109,110)\end{array}$ & $\begin{array}{l}\text { Combination of } \\
\text { miR-9-3p with } \\
\text { AZD6244 for } \\
\text { CD29 (94) }\end{array}$ \\
\hline
\end{tabular}

ALDH1: Aldehyde dehydrogenase 1; ATRA: all-trans retinoic acid; BMI-1: polycomb complex protein BMI-1; BRCA1: breast cancer 1; CD44: hyaluronan receptor; CD24: signal transducer CD24; CTCs: circulating tumor cells; CHK1: checkpoint homolog 1; DCIS: ductal carcinoma in situ; DEAB: diethylaminobenzaldehyde; DFS: disease-free survival; EMT: epithelial-mesenchymal transition; EpCAM: epithelial cell adhesion molecule; ER: estrogen receptor; EZH2: Enhancer of zeste homolog 2; FGFR1: fibroblast growth factor receptor 1; GSTpi: glutathione S-transferase PI; HER2: human epidermal growth factor type 2; HIF-1/2 $\alpha$ : hypoxia-inducible factors 1 and $2 \alpha$; HOXA-1: Homeobox A1; IBC: invasive breast cancer; IL1 $\alpha$ : Interleukin-1 $\alpha$; IL6: interleukin-6; 1L $\beta$ : interleukin- $\beta$; MUC4: Mucin 4; NANOG: Nanog homeobox; NOD/SCID: non-obese diabetic/severe combined immunodeficiency; OS: overall survival; ROS: reactive oxygen species; SNAI1: zinc finger protein SNAI1; SOX1: SRY-box 1; SOX2: SRY-box 2; STAT1: signal transducer and activator of transcription 1; STAT3: signal transducer and activator of transcription 3; TGF $\beta 2$ : transforming growth factor-beta 2; TNBC: triple-negative breast cancer; TWIST: Twist-related protein 1; uPA: urokinase plasminogen activator. 
effect in eradicating CSCs upon its administration with doxorubicin $(33,34)$. Indeed, this compound is believed to interfere directly with the tumorigenesis of $\mathrm{CD} 44^{+} / \mathrm{CD} 24^{-/ \text {low }}$ tumor cells and to prevent neoplastic mammary lesions (35). Other promising compounds are being tested in order to target $\mathrm{CD} 44^{+} / \mathrm{CD} 24^{-/ \text {low }}$ tumor cells (Table I), although their potential still needs to be proven (36-38).

With all the experimental studies performed regarding this phenotype, it has become clear that $\mathrm{CD} 44^{+} / \mathrm{CD} 24^{-/ \text {low }}$ cellsurface markers are enriched for tumorigenic cells in some but not all breast cancers. Hence, the validity of the combination of these markers as being definitive of BCSCs has been called into question and additional markers have been reported, such as ALDH1 (39).

\section{ALDH1}

ALDH1 is broadly used as a functional marker in various types of cancer. Ginestier et al. were the first to demonstrate ALDH1 activity as a marker of stemness in normal and malignant breast cells. They were able to generate a stable tumor via orthotopic injection of 500 ALDH1-positive cells (evaluable by the ALDEFLUOR assay) into the mammary fat pads of non-obese diabetic/severe combined immunodeficiency $(N O D / S C I D)$ mice. Such tumorigenic ability of ALDEFLUOR-positive cells was also seen to be increased when shared with the $\mathrm{CD} 44^{+} / \mathrm{CD} 24^{-/ \text {low }}$ phenotype, since as few as 20 of such cells were sufficient to generate tumors in animals (2). Nonetheless, functional studies revealed that $\mathrm{ALDH}^{+}$cells were more prone to form colonies and tumors than $\mathrm{CD} 44^{+} / \mathrm{CD} 24^{-/ \text {low }}$ cells and also to be more chemoresistant $(2,40)$.

Several immunological studies have attempted to assess ALDH1 as a prognostic marker in breast cancer. The same study of Ginestier et al. with a cohort comprising 577 breast tumors from two independent tumor sets showed a prevalence of $30 \%$ for ALDH1 positivity and its correlation with high histological grade, HER2 overexpression and absence of estrogen receptor and progesterone receptor expression (2). ALDH1 was also demonstrated to be an independent prognostic factor and the same result was obtained in a group of 80 patients who underwent breastconserving therapy. However, no association between tumor ALDH1 staining and micrometastatic disease was noted (41). In a larger cohort of more than 200 patients with primary breast cancer, Morimoto et al. reported a tendency for a worse prognosis in those with high ALDH1 expression (42). Nonetheless and regarding the type of cells expressing ALDH1, a well-designed study from Resetkova and colleagues found that ALDH1 expression in the stromal compartment of two cohorts of triple-negative breast tumors had prognostic significance, although being associated with good rather than poor DFS (43).
ALDH1 expression and clinical outcomes were also explored in inflammatory breast cancer (a particularly lethal form of breast cancer characterized by exaggerated lymphovascular invasion), revealing that ALDH1 expression was a predictive factor for early metastasis and reduced survival (44). On the contrary, in another study, no significant correlation between ALDH1 expression and clinicopathological variables was obtained, despite a trend toward association with a poorer OS (45).

With all these contradictory results, the reliability of ALDH1 expression as a clinical predictor of response to treatment is doubtful, thus enhancing the need for a standard protocol and evaluation process, as well as consideration of the differences between whole-tissue staining versus tissue microarray staining (46). Consistent findings between the reported studies are shown in Table I.

Functional observations associated with ALDH1 are increased levels of NOTCH and $\beta$-catenin, which regulate the deacetylation process of ALDH1, increasing its tumorigenicity in vivo and contributing to a poor clinical outcome. Increased expression of hypoxia-inducible factors 1 and $2 \alpha$ was also shown to be associated with ALDH1 activity and believed to raise the metastatic propensity of ALDH1 $1^{\text {high }}$ cells $(6,47,48)$. Furthermore, increased expression of homeobox A1 and mucin 4 were associated with high ALDH1 activity, also contributing to tumor relapse and metastasis. Activation of transforming grow factor-beta 2 signaling pathway was also shown to be involved in the pathological regulation of ALDH1 in breast cancer (49-51).

Using the $\mathrm{ALDH}^{\text {high }} / \mathrm{CD} 44^{+} / \mathrm{CD} 24^{-/ \text {low }}$ and $\mathrm{ALDH}^{\text {high }}$ phenotypes, Croker et al. (52) and Charafe-Jauffret et al. (14), respectively, provided the first direct experimental evidence implicating $\mathrm{ALDH}^{\text {high }}$ cells in breast cancer metastases in vivo. Cells with a CSC phenotype characterized by ALDH activity were shown to have an improved ability for metastatic behavior in vitro (adhesion, colony formation, migration, and invasion) and metastases in vivo, supporting the hypothesis that CSCs might act as metastasis-initiating cells $(14,49,52-54)$.

ALDH1 is also involved in metabolizing chemotherapeutic drugs so its inhibition was believed to contribute to the reduction or elimination of BCSCs. Indeed, significant resistance to sequential paclitaxel- and epirubicin-based chemotherapy was found in tumor cells expressing ALDH1 (40). The inhibition of ALDH1 activity was also demonstrated to reduce stem cell-like properties and resistance to drugs and radiotherapy (54). As a consequence, these findings have emphasized the need to target ALDH1 ${ }^{+}$ tumor cells in breast cancer treatment.

Even though studies evaluating the impact of pharmacological or immune targeting of ALDH on metastases in vivo are sparse, most showed a decrease of the metastatic burden. In this way, rationalized small-molecule discovery 
has been proposed as a viable methodology to overcome these difficulties and such improvement has led to the current development and generation of isoform-specific ALDH inhibitors (Table I). Salinomycin (an inhibitor of the WNT signaling pathway) is currently the most promising chemotherapeutic drug demonstrated to inhibit the distinctive phenotypic properties of CSCs rather than inducing apoptosis of these cells (10). These findings underline the potential therapeutic value of targeting these properties to reduce the likelihood of tumor recurrence following chemotherapy.

Despite the enrichment of CSCs in $\mathrm{ALDH} 1^{+}$populations reported in several tissues, enzymatic activity measured by ALDEFLUOR alone is much more transient than the expression of traditional cell-surface markers. The usefulness of ALDH1 activity as a sole marker of CSCs may then be limited but can be increased if cells are stained simultaneously for ALDH1 activity and for more stable markers such as CD44 or CD133 (55).

\section{CD44 $^{+} /$ALDH1 $^{+/ h i g h}$ Phenotype}

The importance of ALDH1 activity in breast cancer has been explored alone and in combination with the $\mathrm{CD} 44^{+} / \mathrm{CD} 24^{-/ \text {low }}$ phenotype. However, analysis of tumor samples revealed that only $1 \%$ of the ALDH-positive cell population had the $\mathrm{CD} 44^{+} / \mathrm{CD} 24^{-/ \text {low }} /$ Lineage $^{-}$phenotype reported for BCSCs (2). In fact, an increase in the population of ALDH1-positive cells but not $\mathrm{CD} 44^{+} / \mathrm{CD} 24^{-/ \text {low }}$ cells has been observed in breast cancer tumor biopsies after neoadjuvant treatment (56). Considering the limited usefulness of ALDH1 activity as a sole marker of BCSCs, other combinations have been studied, such is the $\mathrm{CD} 44^{+} / \mathrm{ALDH} 1^{+/ \text {high }}$ phenotype. This phenotype was recently demonstrated to have high tumorigenic ability in breast cancer cell lines and also a highly metastatic propensity, being resistant to standard cancer therapies (54).

An interesting in situ method to define CSCs in formalinfixed paraffin-embedded breast cancer tissues through a quantitative immunofluorescence method was designed by Neumeister and colleagues in order to measure the coexpression of CD44, ALDH1 and cytokeratin. Using a retrospective collection of 321 node-negative and 318 nodepositive cases, localization of $\mathrm{CD} 44^{+} / \mathrm{ALDH} 1^{+}$cells was shown within the epithelial (cytokeratin) compartment of breast tumor tissue. Even if this coexpression was seen in variably sized clusters and only in $6 \%$ of cases, such combination conferred a significantly worse outcome, being able to identify high-risk patients in breast cancer (12). Our research group has also studied the coexpression of CD44 and ALDH1, and remarkably, such combined expression was seen to be higher in ductal carcinomas in situ (DCIS) when compared with invasive ductal carcinomas (IDCs) of the breast, enhancing the tumorigenic potential of these putative
BCSCs (57). More interestingly, in a cohort comprising 250 patients with different benign and malignant breast lesions, we also demonstrated that the $\mathrm{CD} 44^{+} / \mathrm{ALDH} 1^{+}$phenotype was significantly increased in high-grade DCIS when compared with IDC. Moreover, this phenotype was found to be predominantly in a quiescent state (negativity for Ki-67 proliferation marker), raising some questions about the true role of dormancy in BCSCs (58).

A gene-expression analysis study revealed an increased expression of NOTCH and $\mathrm{WNT} / \beta$-catenin signaling pathways in $\mathrm{CD} 44^{+} / \mathrm{ALDH} 1^{+}$breast cancer cells isolated from an IBC cell line (59). However, concerning this phenotype, further genetic and even epigenetic analysis are required in order to better understand its behavior in breast cancer progression. Like CD $44^{+} / \mathrm{CD} 24^{-/ \text {low }}$ and ALDH1positive tumor cells, it would be also interesting to depict the mechanisms that drive the progression of $\mathrm{CD} 44^{+} / \mathrm{ALDH} 1^{+}$ tumor cells.

Indeed, Croker and Allan directly inhibited ALDH activity with the specific ALDH inhibitor diethylaminobenzaldehyde (DEAB) and indirectly through all-trans retinoic acid (ATRA). They isolated $\mathrm{ALDH}^{\mathrm{high}} / \mathrm{CD} 44^{+}$and $\mathrm{ALDH}^{\text {low }} / \mathrm{CD} 44^{-}$ populations and demonstrated that $\mathrm{ALDH} \mathrm{H}^{\text {high }} / \mathrm{CD} 44^{+}$human breast cancer cells were resistant to certain chemotherapy drugs (54). For that, they subjected both populations to treatment with doxorubicin, paclitaxel or radiation in the presence or absence of DEAB or ATRA and concluded that the reduction in cell viability was significantly greater in the $\mathrm{ALDH}^{\mathrm{high}} / \mathrm{CD}_{4} 4^{+}$population. Furthermore, and in contrast to $\mathrm{ALDH}^{\mathrm{low}} / \mathrm{CD}_{4} 4^{-}$cells, ALDH ${ }^{\text {high }} / \mathrm{CD} 44^{+}$cells showed increased basal activity in a series of DNA response proteins including P-glycoprotein, glutathione-S-transferase pi and checkpoint homolog 1 (CHK1) (Table I).

Although such results enhance the need for targeting $\mathrm{CD} 44^{+} / \mathrm{ALDH} 1^{+}$tumor cells in breast cancer, no other agents or drugs have been developed to directly target this phenotype. Only inhibitors that target $\mathrm{CD} 44^{+} / \mathrm{CD} 24^{-/ \text {low }}$ tumor cells or $\mathrm{ALDH}^{+}$tumor cells were shown to be promising. Despite the current improvements regarding the adverse effects of ALDH1 and CD44 for breast cancer treatment, additional studies in order to infer about the tumorigenic and metastatic ability of $\mathrm{CD} 44^{+} / \mathrm{ALDH} 1^{+/ \text {high }}$ tumor cells still have to be depicted. Besides that, the development of additional promising inhibitors to target this phenotype is also needed.

\section{CD133 (Prominin-1)}

CD133 has been recently included in CSC research. It is also named prominin-1 for its prominent location on the protrusion of cell membranes and was the first gene identified in those for a class of novel pentaspan transmembrane glycoproteins. Although it was initially 
considered to be a marker of hematopoietic stem cells, CD133 mRNA transcript is also found in normal nonlymphoid hematopoietic tissue (60) and has been shown to play a role in SC migration and asymmetric division (61). CD133 was reported to be overexpressed in several solid tumors $(62,63)$, including colon cancer and glioblastoma $(64,65)$. In IBCs, CD133 expression was demonstrated by Liu et al. (66), where they assumed that its expression could be of help in a more accurate prediction of breast cancer aggressiveness and determination of the most suitable treatment. Actually, in BRCA1-associated breast cancer cell lines, $\mathrm{CD}_{133^{+}}$sorted cells were shown to have CSC properties, including a greater colony-forming efficiency, higher proliferative output and greater capability to form tumors in NOD/SCID mice (67). Moreover, CD133 was also proved to be suitable in the identification of CSCs in triplenegative breast cancers through several in vitro $(68,69)$ and in vivo studies (70). In addition, the recent use of CD133 to detect circulating tumor cells in patients with triple-negative breast cancer $(71,72)$ has increased the attention on this marker, emphasizing its role in prognosis in this breast cancer subtype. Expression of CD133 was also recently reported in 22 out of 25 cases of inflammatory breast cancer (13). Taken together, these interesting results indicate the need for more advanced research to understand the role of CD133 in BCSCs.

Expression of SC-associated genes, such as NOTCH1, ALDH1, fibroblast growth factor receptor 1 and SRY-box 1, was shown to be increased not only in $\mathrm{CD} 44^{+} / \mathrm{CD} 24^{-/ \mathrm{low}}$ but also in $\mathrm{CD}_{133^{+}}$breast cancer cells (67). Xenograft-initiating breast cancer cells enriched in CD $44^{+} / \mathrm{CD} 49 \mathrm{f}^{\text {high} /}$ CD133/2 high cells were also shown to have elevated expression of Nanog homeobox (NANOG), SRY-box 2, and polycomb complex protein BMI-1 (73). Further extensive CD133 profiling in breast cancer needs to be performed to confirm CD $133^{+}$breast cancer cells as tumor-initiating cells.

Due to the increasing importance of CD133 expression in breast cancer progression, attempts have been made to correlate its expression with tumor relapse and resistance to chemotherapeutic agents. In fact, CD133 expression was reported to be correlated with tumor recurrence in patients with breast cancer (74). In drug-sensitive MCF-7 cells, only a small fraction of cells was found to be CD133-positive (75). In another interesting study, polymeric nanoparticles loaded with paclitaxel and surface functionalized with antibody to CD133 demonstrated efficient elimination of tumor-initiating cells in vitro and significant inhibition of tumor regrowth in vivo (76). With such results, CD133 is regarded as a potential target for anticancer therapeutics, being possible to reduce tumor recurrence in breast cancer through the elimination of $\mathrm{CD} 133^{+}$cells. Thus, additional studies investigating specific drugs that efficiently target this protein are required.

\section{Integrins}

The use of the integrins CD29 $(\beta 1)$ and CD49f $(\alpha 6)$ in combination with CD24 was recently demonstrated to be able to identify mouse mammary $\operatorname{SCs}(77,78)$. Since all previously described SC markers were shown not only to identify normal mammary SCs but also to isolate BCSCs, Vassilopolus et al. used CD24/CD29 and CD24/CD49f to successfully identify a subpopulation of mammary tumor cells (79). Such demonstration highlighted the importance of CD29 and CD49f in BCSCs. CD49f heterodimerizes with either the CD29 or CD104 ( $\beta 4$ integrin) subunits to generate the CD49fCD29 and CD49fCD104 integrins, which function primarily as laminin receptors (80). In addition, CD49f cooperates with receptor tyrosine kinases to communicate, bidirectionally, between the cell and the extracellular matrix (ECM). Interestingly, however, the CD104 subunit appears to be expressed at very low levels, if at all in CSCs when compared to non-CSCs indicating that CD49fCD29 is the dominant integrin expressed by CSCs $(81,82)$.

CD29 represents the predominant integrin in mammary epithelial cells in mice, and is aberrantly expressed in human breast carcinomas, contributing to diverse malignant phenotypes, including EMT, metastasis and angiogenesis (8285). Moreover, in patients with IBC, high CD29 expression was found to be associated with significantly shorter DFS and OS $(86,87)$. In human breast cancer, CD49f integrin is overexpressed and was shown to be an independent prognostic factor of a poor outcome (88). CD49f ${ }^{+}$cancer cells were also associated with a higher probability of distant metastasis after initial surgery and poor clinical outcomes with respect to both DFS and OS (89). Additionally, normal human SCs and myoepithelial progenitor cells characterized by $\mathrm{CD} 49^{\text {high }} /$ epithelial cell adhesion molecule (EpCAM) ${ }^{-}$ cells were shown to express vimentin, a common EMT marker, suggesting that some cells may have been undergoing EMT (90). Interestingly, an aberrant luminal progenitor cell population $\left(\mathrm{EpCAM}^{+} / \mathrm{CD} 4 \mathrm{f}^{+}\right.$) was also proposed to be the cell origin of BRCA1-associated basal breast cancer (91).

Functional analysis revealed that while knockdown of $C D 29$ or $C D 49 f$ alone slightly reduced cell migration ability in BRCA1-mutant cancer cell lines, knockdown of both genes caused a profound effect, blocking migration, suggesting an overlapping, yet critical function of both genes in the migration of BCSCs (79). Such an interesting finding supports the notion that both integrins can pair with each other in order to form heterodimers for ECM components such as fibronectin and laminin (80). Consistent with the assumption that a malignant social network mediates cellcell adhesion and communication between CSCs and their microenvironment (92), both integrins may be implicated in mediating such a network. Specifically, CD29/CD49f integrins may mediate $\mathrm{CSC}-$ stromal interaction, relaying 
ECM signaling to cellular machinery, leading to the increased activity of CSCs in terms of viability, differentiation and metastasis (79).

Although the CD29/CD49f integrins have been implicated in the function of BCSCs and other CSCs $(81,82,93)$, much needs to be learned about the contribution of these integrins to the genesis of BCSCs. It has been shown that CD49f and CD29 contribute to therapy resistance, tumor relapse and metastasis in breast cancer. As a consequence, the development of inhibitors that could potentially target these two integrins in breast cancer is required (Table I). Interesting studies have been published with promising results in targeting these integrins such as through the use of short hairpin RNAs or micro-RNAs (94). Targeting gene signaling pathways associated with these integrins or even specific kinases such as feline sarcoma-related kinase, which controls migration and metastasis of IBC cell lines by regulating CD49f- and CD29-integrin-dependent adhesion, is also an interesting approach (95).

\section{Breast Cancer Stem Cells and Next-Generation Sequencing}

The continuous improvements of next-generation sequencing (NGS) technologies currently allow the analysis of hundreds of genes in just one population of cells, or even in one single cell $(96,97)$. Such application has opened a new window in the genomic field where a mutational, time-based lineage tree can now be delineated for a specific subtype of cancer considered to be highly aggressive. In this way and with NGS, it is possible to determine other genes from those already associated with being oncogenic, or, more importantly, to assess which mutated genes are responsible for driving tumorigenesis, considering the high levels of heterogeneity in cancer, especially in breast cancer (98). In fact, NGS has recently been used for the analysis of the molecular features of early-stage breast cancer leading to a genomic portrait of this disease. Within such a portrait, tumor suppressor p53 (TP53) and phosphatidylinositol-4,5-bisphosphate 3-kinase catalytic subunit alpha $(P I K 3 C A)$ mutations were the most frequent genomic alterations found in all breast cancer subtypes. Clinical relevance of phosphatase and tensin homolog $(P T E N)$ mutations and deletions as well as those of $\mathrm{v}$-akt murine thymoma viral oncogene homolog 1 (AKTl), $B R C A 1$ and BRCA2 was also highlighted (99).

With this in mind, such technology would allow the definition of a mutational repertoire of each subpopulation of BCSCs presented here. Klevebring et al. undertook exome sequencing of CSCs (characterized by CD $44^{+} / \mathrm{CD} 24^{-}$and expression of ALDH1) from 12 patients with breast cancer, along with paired primary tumor samples. They found that the vast majority of mutations were shared between CSCs and the bulk primary tumor, as was the observed distribution of allelic frequencies, suggesting that a dynamic transition between cellular states (CSC and differentiated state) takes place continuously throughout the tumor development (100). Even using a small cohort, through NGS, our research group was able to detect somatic mutations in $\mathrm{CD} 44^{+} / \mathrm{CD} 24^{-/ \mathrm{low}} /$ $\mathrm{Ck}^{+} / \mathrm{CD} 45^{-}$breast cells isolated from non-malignant and malignant breast lesions. Mutations affecting the TP53, NOTCH1, GTPase HRas (HRAS), AKT1, PTEN, colonystimulating factor 1 receptor $(C S F 1 R)$ and ret protooncogene $(R E T)$ genes were detected in the malignant lesions, suggesting a heterogeneous molecular profile of these BCSCs (101). Thus, a practical example would be the application of NGS in isolated BCSCs (defined by different combinations of BCSC markers) from primary tumors and their corresponding metastases in order to determine which gene is more frequently mutated (hotspot mutations) in each subpopulation of BCSCs. Such an approach would be of great importance for the development of additional therapeutic drugs that could be promising not only for the most well-known BCSC markers (CD44, CD24 and ALDH1), but also for the discovery of new targets directly associated with other BCSC markers, such as CD133 or integrins.

In the future, this growing technology will definitely revolutionize CSC research, by providing new deregulated gene signaling pathways directly involved in the progression of tumor-initiating cells already proven to have stem cell properties, particularly in breast cancer.

\section{Acknowledgements}

The Authors would like to thank the Foundation for Science and Technology (Portugal). Scholarship reference: SFRH/BD/74307/2010 (ACP).

\section{References}

1 Al-Hajj M, Whicha MS, Bentio-Hernandez A, Morrison SJ and Clarke MF: Prospective identification of tumorigenic breast cancer cells. Proc Natl Acad Sci 100: 3983-3988, 2003.

2 Ginestier C, Hur MH, Charafe-Jauffret E, Monville F, Ducther J, Brown M, Jacquemier J, Viens P, Kleer CG, Liu S, Schott A, Hayes D, Birnbaum D, Wicha MS and Dontu G: ALDH1 is a marker of normal and malignant human mammary stem cells and a predictor of poor clinical outcome. Cell Stem Cell 1: 555567, 2007.

3 Sheridan C, Kishimoto H, Fuchs RK, Mehrotra S, BhatNakshatri P, Turner CH, Goulet R, Badve S and Nakshatri H: $\mathrm{CD} 44^{+} / \mathrm{CD} 24^{-}$breast cancer cells exhibit enhanced invasive properties: an early step necessary for metastasis. Breast Cancer Res 8: R59, 2006.

4 Li X, Lewis MT, Huang J, Gutierrez C, Osborne CK, Hu MF, Hilsenbeck SG, Pavlick A, Zhang X, Chamness GC, Wong H, Rosen $\mathrm{J}$ and Chang JC: Intrinsic resistance of tumorigenic breast cancer cells to chemotherapy. J Natl Cancer Inst 100: 672-679, 2008. 
5 Diehn M, Cho RW, Lobo NA, Kalisky T, Dorie MJ, Kulp AN, Qian D, Lam JS, Ailles LE, Wong M, Joshua B, Kaplan MJ, Wapnir I, Dirbas FM, Somlo G, Garberoglio C, Paz B, Shen J, Lau SK, Quake SR, Brown JM, Weissman IL, and Clarke MF: Association of reactive oxygen species levels and radioresistance in cancer stem cells. Nature 458: 780-783, 2009.

6 Jang GB, Hong IS, Kim RJ, Lee SY, Park SJ, Lee ES, Park JH, Yun $\mathrm{CH}$, Chung JU, Lee KJ, Lee HY and Nam JS: WNT/ $\beta$ catenin small-molecule inhibitor CWP232228 preferentially inhibits the growth of breast cancer stem-like cells. Cancer Res 75: 1691-1702, 2015.

7 Rodriguez-Torres M and Allan AL: Aldehyde dehydrogenase as a marker and functional mediator of metastasis in solid tumors. Clin Exp Met 33: 1-17, 2015.

8 Gupta PB, Filmore CM, Jiang G, Shapira SD, Tao K, Kuperwasser C and Lander ES: Stochastic state transitions give rise to phenotypic equilibrium in populations of cancer cells. Cell 146: 633-644, 2011.

9 Schott AF, Landis MD, Dontu G, Griffith KA, Layman RM, Krop I, Paskett LA, Wong H, Dobrolecki LE, Lewis MT, Froehlich AM, Paranilam J, Hayes DH, Wicha MS and Chang JC: Preclinical and clinical studies of gamma secretase inhibitors with docetaxel on human breast tumors. Clin Cancer Res 19: 1512-1524, 2013.

10 An H, Kim JY, Lee N, Cho Y, Oh E and Seo JH: Salinomycin possesses anti-tumor activity and inhibits breast cancer stemlike cells via an apoptosis-independent pathway. Biochem Biophys Res 466: 696-703, 2015.

11 Martelotto LG, Ng CK, Piscuoglio S, Weigelt B and Reis-Filho JS: Breast cancer intra-tumor heterogeneity. Breast Cancer Res 16: 210, 2014.

12 Neumeister V, Agarwal S, Bordeaux J, Camp RL and Rimm DL: In situ identification of putative cancer stem cells by multiplexing ALDH1, CD44, and cytokeratin identifies breast cancer patients with poor prognosis. Am J Pathol 176: 2131 2138, 2010.

13 Xiao Y, Ye Y, Yearsley K, Jones S and Barsky SH: The lymphovascular embolus of inflammatory breast cancer expresses a stem cell-like phenotype. Am J Pathol 173: 561-574, 2008.

14 Croker AK, Goodale D, Chu J, Postenka C, Hedley BD, Hess DA, and Allan AL: High aldehyde dehydrogenase and expression of cancer stem cell markers selects for breast cancer cells with enhanced malignant and metastatic ability. J Cell Mol Med 13: 2236-2252, 2009.

15 Park SY, Lee HE, Li H, Shipitsin M, Gelman R and Polyak K: Heterogeneity for stem cell-related markers according to tumor subtype and histologic stage in breast cancer. Clin Cancer Res 16: 876-887, 2010.

16 Abraham BK, Fritz P, McClellan M, Hauptvogel P, Athelogou M and Brauch H: Prevalence of CD44+/CD24-/low cells in breast cancer may not be associated with clinical outcome but may favor distant metastasis. Clin Cancer Res 11: 1154-1159, 2005.

17 Bernardi M, Logullo AF, Pasini FS, Nonogaki S, Blumke C, Soares FA, and Brentani MM: Prognostic significance of CD24 and claudin-7 immunoexpression in ductal invasive breast cancer. Oncol Rep 27: 28-38, 2012.

18 Bane A, Viloria-Petit A, Pinnaduwage D, Mulligan AM, O'Malley FP and Andrulis IL: Clinical-pathologic significance of cancer stem cell marker expression in familial breast cancers. Breast Cancer Res Treat 140: 195-205, 2013.
19 Liu R, Wang X, Chen GY, Dalerba P, Gurney A, Hoey T, Sherlock G, Lewicki J, Shedden K and Clarke MF: The prognostic role of a gene signature from tumorigenic breastcancer cells. N Eng J Med 356: 217-226, 2007.

20 Bertucci F, Cervera N and Birnbaum D: A gene signature in breast cancer. N Eng J Med 356: 1887-1888, 2007.

21 Ding XW, Wu JH and Jiang CP: ABCG2: a potential marker of stem cells and novel target in stem cell and cancer therapy. Life Sciences 86: 631-637, 2010.

22 Doyle LA, Yang W, Abruzzo LV, Krogmann T, Gao Y, Rishi $\mathrm{AK}$ and Ross DD: A multidrug resistance transporter from human MCF-7 breast cancer cells. Proc Natl Acad Sci 95: 15665-15670, 1998.

23 Lagadec C, Vlashi E, Donna LD, Meng YH, Dekmezian C, Kim K and Pajonk F: Survival and self-renewing capacity of breast cancer initiating cells during fractionated radiation treatment. Breast Cancer Res 12: R13, 2010.

24 Mani SA, Guo W, Liao MJ, Eaton EN, Ayyanan A, Zhou AY, Brooks M, Reinhard F, Zhang CC, Shipitsin M, Campbell LL, Polyak K, Brisken C, Yang J and Weinberg RA: The epithelialmesenchymal transition generates cells with properties of stem cells. Cell 133: 704-715, 2008.

25 Trumpp A and Wiestler OD: Mechanisms of disease: cancer stem cells-targeting the evil twin. Nat Clin Pract Oncol 5: 337$347,2008$.

26 Woodward WA, Chen MS, Behbod F, Alfaro MP, Buchholz TA and Rosen JM: WNT/ $\beta$-catenin mediates radiation resistance of mouse mammary progenitor cells. Proc Natl Acad Sci 104: 618-623, 2007.

27 Lewis MT and Veltmaat JM: Next stop, the twilight zone: hedgehog network regulation of mammary gland development. J Mammary Gland Biol Neoplasia 9: 165-181, 2004.

28 Phillips TM, McBride WH, and Pajonk F: The response of CD24-/low/CD44+ breast cancer-initiating cells to radiation. J Natl Cancer Inst 98: 1777-1785, 2006.

29 Zhan JF, Chen L, Yuan Y, Xie G, Sun A, Liu Y and Chen ZX: STAT1 promotes radioresistance of CD44+/CD24-/low cells in breast cancer. Exp Biol Med 236: 418-422, 2011.

30 Wei W, Tweardy DJ, Zhang M, Landua J, Petrovic I, Bu W, Roarty K, Hilsenbeck SG, Rosen JM and Lewis MT: STAT3 Signaling is activated preferentially in tumor-initiating cells in claudin-low models of human breast cancer. Stem Cells 32: 2571-2582, 2014.

31 Olsauskas-Kuprys R, Zlobin A and Osipo C: Gamma secretase inhibitors of NOTCH signaling. Onco Targets Ther 6: 943-955, 2013.

32 Zhang CC, Pavlicek A, Zhang Q, Lira ME, Painter CL, Yan Z, Zheng X, Lee NV, Ozek M, Qiu M, Zong Q, Lappin PB, Wong A, Rejto PA, Smeal $\mathrm{T}$ and Christensen JG: Biomarker and pharmacologic evaluation of the $\gamma$-secretase inhibitor PF-03084014 in breast cancer models. Clin Cancer Res 18: 5008-5019, 2012.

33 Hirsch HA, Lliopoulos D, Tsichlis PN and Struhl P: Metformin selectively targets cancer stem cells, and acts together with chemotherapy to block tumor growth and prolong remission. Cancer Res 69: 7507-7511, 2009.

34 Cufí S, Coromina-Faja B, Vazquez-Martin A, Cristina OF, Joan DR, Joaquim BB, Begona MC and Abel MM: Metformininduced preferential killing of breast cancer initiating CD44+ $\mathrm{CD} 24^{-/ \text {low }}$ cells is sufficient to overcome primary resistance to trastuzumab in HER2+ human breast cancer xenografts. Oncotarget 3: 395-398, 2012. 
35 Zhu P, Davis M, Blackwelder AJ, Bachman N, Liu B, Edgerton S, Williams LL, Thor AD and Yang X: Metformin selectively targets tumor-initiating cells in ERBB2-overexpressing breast cancer models. Cancer Prev Res 7: 199-210, 2014.

36 Wang TC, Chao TK, Chang CC, Yo YT, Yu MH and Lai HC: Drug screening identifies niclosamide as an inhibitor of breast cancer stem-like cells. PloS One 8: e74538, 2013.

37 Yip N, Fonbom IS, Liu P, Brown S, Kannappan V, Armesilla $\mathrm{AL}, \mathrm{Xu} \mathrm{B}$, Cassidy J, Darling JL and Wang W: Disulfiram modulated ROS-MAPK and NFKB pathways and targeted breast cancer cells with cancer stem cell-like properties. Br J Cancer 104: 1564-1574, 2011.

38 Zielske SP, Spalding AC and Lawrence TS: Loss of tumorinitiating cell activity in cyclophosphamide-treated breast xenografts. Trans Oncol 3: 149-152, 2010.

39 Shipitsin M, Campbell LL, Argani P, Weremowicz S, Bloushtain-Qimron N, Yao J, Nikolskaya T, Serebryiskaya T, Beroukhim R, Hou M, Haloushka MK, Sukumar S, Parker LM, Anderson KS, Harris LN, Garber JE, Richardson AL, Schnitt SJ, Nikolsky Y, Gelman RS and Polyak K: Molecular definition of breast tumor heterogeneity. Cancer Cell 11: 259-273, 2007.

40 Tanei T, Morimoto K, Shimazu K, Kim SJ, Tanji Y, Tagushi T, Tamaki Y and Nogushi T: Association of breast cancer stem cells identified by aldehyde dehydrogenase 1 expression with resistance to sequential paclitaxel and epirubicin-based chemotherapy for breast cancers. Clin Cancer Res 15: 42344241, 2009.

41 Woodward WA, Krishnamurthy S, Lodhi A, Xiao L, Cong Y, Cristofanilli M, Buchholz TA and Lucci A: Aldehyde dehydrogenase 1 immunohistochemical staining in primary breast cancer cells independently predicted overall survival but did not correlate with the presence of circulating or disseminated tumors cells. J Cancer 5: 360-367, 2014.

42 Morimoto K, Kim SJ, Tanei T, Shimazu K, Tanji Y, Tagushi T, Tamaki Y, Terada N and Nogushi S: Stem cell marker aldehyde dehydrogenase 1-positive breast cancers are characterized by negative estrogen receptor, positive human epidermal growth factor receptor type 2, and high Ki67 expression. Cancer Sci 100: 1062-1068, 2009.

43 Resetkova E, Reis-Filho JS, Jain RK, Mehta R, Thorat MA, Nakshatri $\mathrm{H}$ and Badve S: Prognostic impact of ALDH1 in breast cancer: a story of stem cells and tumor microenvironment. Breast Cancer Res Treat 123: 97-108, 2010.

44 Charafe-Jauffret E, Ginestier C, Lovino F, Tarpin C, Diebel M, Esterni B, Houvenaeghel G, Extra JM, Bertucci F, Jacquemier J, Xerri L, Dontu G, Stassi G, Xiao Y, Barsky SH, Birnbaum D, Viens P and Whicha MS: Aldehyde dehydrogenase 1positive cancer stem cells mediate metastasis and poor clinical outcome in inflammatory breast cancer. Clin Cancer Res 16: $45-55,2010$

45 Gong Y, Wang J, Huo L, Wei W and Ueno NT: Aldehyde dehydrogenase 1 expression in inflammatory breast cancer as measured by immunohistochemical staining. Clin Breast Cancer 14: e81-e88, 2014

46 Wolfe AR and Woodward WA: Breast cancer stem cell correlates as predicative factors for radiation therapy. Sem Rad Oncol 25: 251-259, 2015.

47 Tiezzi DG, Clagnan WS, Mandarano LMR, de Sousa CB, Marana HRC, Tiezzi MG and Andrade JM: Expression of aldehyde dehydrogenase after neoadjuvant chemotherapy is associated with expression of hypoxia-inducible factors 1 and 2 alpha and predicts prognosis in locally advanced breast cancer. Clinics 68: 592-598, 2013.

48 Zhao D, Mo Y, Li MT, Zhou SW, Cheng ZL, Sun YP, Xiong Y, Guan KL and Lei QY: NOTCH-induced aldehyde dehydrogenase $1 \mathrm{~A} 1$ deacetylation promotes breast cancer stem cells. J Clin Inv 124: 5453, 2014.

49 Marcato P, Dean CA, Liu RZ, Coyle KM, Bydoun M, Wallace M, Clements D, Turner C, Mathenge EG, Gujar SA, Giacomoantonio CA, Mackey JR, Godbout R and Lee PWK: Aldehyde dehydrogenase $1 \mathrm{~A} 3$ influences breast cancer progression via differential retinoic acid signaling. Mol Oncol 9: 17-31, 2015.

50 Bhola NE, Balko JM, Dugger TC, Kuba MG, Sánchez V, Sanders M, Stanford J, Cook RS and Arteaga CL: TGF- $\beta$ inhibition enhances chemotherapy action against triple-negative breast cancer. J Clin Inv 123: 1348, 2013.

51 Zheng R, Wang J, Wu Q, Ou Y, Wang Z, Ma L, Wang M, Wang $\mathrm{J}$ and Yan Y: Expression of ALDH1 and TGF $\beta 2$ in benign and malignant breast tumors and their prognostic implications. Int J Clin Exp Pathol 7: 4173, 2014.

52 Charafe-Jauffret E, Ginestier C, Lovino F, Wicinski J, Cervera $\mathrm{N}$, Finetti P, Hur MR, Diebel ME, Monville F, Dutcher J, Brown M, Viens P, Xerri L, Bertucci F, Stassi G, Dontu G, Birnbaum D and Whicha MS: Breast cancer cell lines contain functional cancer stem cells with metastatic capacity and a distinct molecular signature. Cancer Res 69: 1302-1313, 2009.

53 Marcato P, Dean CA, Pan D, Araslanova R, Gillis M, Joshi M, Helyer L, Pan L, Leidal A, Gujar S, Giacomoantonio CA and Lee PWK: Aldehyde dehydrogenase activity of breast cancer stem cells is primarily due to isoform ALDH1A3 and its expression is predictive of metastasis. Stem Cells 29: 32-45, 2011.

54 Croker AK and Allan AL: Inhibition of aldehyde dehydrogenase (ALDH) activity reduces chemotherapy and radiation resistance of stem-like $\mathrm{ALDH}{ }^{\text {hi }} \mathrm{CD} 44^{+}$human breast cancer cells. Breast Cancer Res Treat 133: 75-87, 2012.

55 Keysar SB and Jimeno J: More than markers: biological significance of cancer stem cell-defining molecules. Mol Cancer Ther 9: 2450-2457, 2010.

56 Lee HE, Kim JH, Kim YJ, Choi SY, Kim SW, Kang E, Chung IY, Kim IA, Choi Y, Ryu HS and Park SY: An increase in cancer stem cell population after primary systemic therapy is a poor prognostic factor in breast cancer. Br J Cancer 104: 17301738, 2011.

57 Paula ADC, Marques O, Rosa AM, Faria MDF, Rêma A and Lopes C: Co-expression of stem cell markers ALDH1 and CD44 in non-malignant and neoplastic lesions of the breast. Anticancer Res 34: 1427-1434, 2014.

58 Paula ADC, Marques O, Sampaio R, Rosa AM, Garcia J, Rêma A, Faria MDF, Silva P, Vizcaíno $R$ and Lopes $C$ : Characterization of $\mathrm{CD} 44^{+} / \mathrm{ALDH} 1^{+} / \mathrm{Ki}-67^{-}$cells in nonmalignant and neoplastic lesions of the breast. Anticancer Res 36: 4629:4638, 2016.

59 Cui J, II P, Liu X, Hu H and Wei W: Abnormal expression of the Notch and Wnt/ $\beta$-catenin signaling pathways in stem-like $\mathrm{ALDH}^{\text {hiCD }} 44^{+}$cells correlates highly with $\mathrm{Ki}-67$ expression in breast cancer. Onco Lett 9: 1600-1606, 2015.

60 Miraglia S, Godfrey W, Yin AH, Atkins K, Warnke R, Holden JT, Bray RA, Waller EK and Buck DW: A novel five-transmembrane hematopoietic stem cell antigen: isolation, characterization, and molecular cloning. Blood 90: 5013-5021, 1997. 
61 Kosodo Y, Roper K, Haubensak W, Marzesco AM, Corbeil D and Huttner WB: Asymmetric distribution of the apical plasma membrane during neurogenic divisions of mammalian neuroepithelial cells. EMBO J 23: 2314-2324, 2004.

62 Hilbe W, Dimhofer S, Oberwasserlechner F, Schmid T, Gunsilius E, Hilbe G, Woll E and Kahler CM: CD133-positive endothelial progenitor cells contribute to the tumour vasculature in non-small cell lung cancer. J Clin Pathol 57: 965-969, 2004.

63 Singh SK, Hawkins C, Clarke ID, Squire JA, Bayani J, Hide T, Henkelman RM, Cusimano MD and Dirks PB: Identification of human brain tumour initiating cells. Nature 432: 396-401, 2004.

64 Ricci-Vitiani L, Lombardi DG, Pilozzi E, Biffoni M, Todaro M, Peschle $\mathrm{C}$ and De Maria R: Identification and expansion of human colon-cancer-initiating cells, Nature 445: 111-115, 2007.

65 Schrot RH, Ma JH, Greco CM, Arias AD and Angelastro JM: Organotypic distribution of stem cell markers in formalin-fixed brain harboring glioblastoma multiforme. J Neuro-Oncol 85: 149-157, 2007.

66 Liu Q, Li JG, Zheng XY, Jin F and Dong H: Expression of CD133, PAX2, ESA, and GPR30 in invasive ductal breast carcinomas. Chin Med J 122: 2763-2769, 2009.

67 Wright MH, Calcagno AM, Salcido CD, MCarlson MD, Ambudkar SV and Varticovski L: Brcal breast tumors contain distinct $\mathrm{CD} 44^{+} / \mathrm{CD} 24^{-}$and $\mathrm{CD} 133^{+}$cells with cancer stem cell characteristics. Breast Cancer Res 10: R10, 2008.

68 Liu L, Sun BC, Zhao XL, Sun T, Gu Q, Yao Z, Dong XY, Zhao $\mathrm{N}$ and Liu N: CD133+; cells with cancer stem cell characteristics associates with vasculogenic mimicry in triplenegative breast cancer. Oncogene 22: 544-553, 2011.

69 Brugnoli F, Grassilli S, Piazzi M, Palomba M, Nika E, Bavelloni A, Capitani S and Bertagnolo V: In triple-negative breast tumor cells, PLC- $\beta 2$ promotes the conversion of CD133 high to CD133low phenotype and reduces the CD133related invasiveness. Mol Cancer 12: 1, 2013.

70 Zhao P, Lu Y, Jiang X and Li X: Clinicopathological significance and prognostic value of CD133 expression in triple-negative breast carcinoma. Cancer Sci 102: 1107-1111, 2011.

71 Nadal R, Ortega FG, Salido M, Lorente JA, Rodriguez-Rivera M, Delgado-Rodriguez M, Macià M, Fernández A, Corominas JM, Garcia-Puche JL, Sánchez-Rovira P, Solé F and Serrano MJ: CD133 expression in circulating tumor cells from breast cancer patients: potential role in resistance to chemotherapy. Int J Cancer 133: 2398-2407, 2013.

72 Bock C, Rack B, Huober J, Andergassen U, Jeschke U and Doisneau-Sixou S: Distinct expression of cytokeratin, Ncadherin and CD133 in circulating tumor cells of metastatic breast cancer patients. Fut Oncol 10: 1751-1765, 2014

73 Meyer MJ, Fleming JM, Lin AF, Hussnain SA, Ginsburg E and Vonderhaar BK: CD44+CD49fhiCD133/2hi defines xenograftinitiating cells in estrogen receptor-negative breast cancer. Cancer Res 70: 4624-4633, 2010.

74 Aomatsu N, Yashiro M, Kashiwagi S, Takashima T, Ishikawa T, Ohsawa M Wakasa K and Hirakawa K: CD133 is a useful surrogate marker for predicting chemosensitivity to neoadjuvant chemotherapy in breast cancer. PloS One 7: e45865, 2012.

75 Wang XY, Penalva LOF, Yuan H, Linnoila RI, Lu J, Okano H and Glazer RI: Musashil regulates breast tumor cell proliferation and is a prognostic indicator of poor survival. Mol Cancer 9: 221, 2010.
76 Swaminathan SK, Roger E, Toti U, Niu L, Ohlfest JR and Panyam J: CD133-targeted paclitaxel delivery inhibits local tumor recurrence in a mouse model of breast cancer. J Control Rel 171: 280-287, 2013.

77 Shackleton M, Vaillant F, Simpson KJ, Stingl J, Smyth GK, Asselin-Labat ML, Wu L, Lindeman GJ and Visvader JE: Generation of a functional mammary gland from a single stem cell. Nature 439: 84-88, 2006.

78 Stingl J, Eirew P, Ricketson I, Shackleton M, Vaillant F, Choi D, Li HI and Eaves CJ: Purification and unique properties of mammary epithelial stem cells. Nature 439: 993-997, 2006.

79 Vassilopoulos A, Wang RH, Petrovas C, Ambrozak D, Koup R and Deng CX: Identification and characterization of cancer initiating cells from BRCA1-related mammary tumors using markers for normal mammary stem cells. Int J Biol Sci 4: 133$142,2008$.

80 Mercurio AM: Laminin: multiple forms, multiple receptors. Curr Op Cell Biol 2: 845-849, 1990.

81 Goel HL, Pursell B, Chang C, Shaw LM, Mao J, Simin K, Kumar P, Kooi CWV, Schultz LD, Greiner DL, Norum JH, Toftgard R, Kuperwasser C and Mercurio AM: GLI1 regulates a novel neuropilin-2/ $\alpha 6 \beta 1$ integrin-based autocrine pathway that contributes to breast cancer initiation. EMBO Mol Med 5: 488-508, 2013.

82 Lathia JD, Gallagher J, Heddleston JM, Wang J, Eyler CE, MacSwords J, Wu Q, Vasanji A, McLendon RE, Hjelmeland $\mathrm{AB}$ and Rich JN: Integrin alpha 6 regulates glioblastoma stem cells. Cell Stem cell 6: 421-432, 2010.

83 Schlaepfer DD and Hunter T: Focal adhesion kinase overexpression enhances RAS-dependent integrin signaling to ERK2/mitogen-activated protein kinase through interactions with and activation of c-SRC. J Biol Chem 272: 13189-13195, 1997.

84 Imanishi Y, Hu B, Jarzynka MJ, Guo P, Elishaev E, Bar-Joseph I and Chen SY: Angiopoietin-2 stimulates breast cancer metastasis through the $\alpha 5 \beta 1$ integrin-mediated pathway. Cancer Res 67: 4254-4263, 2007.

85 Jahangiri A, Aghi MK and Carbonell WS: $\beta 1$ Integrin: Critical path to antiangiogenic therapy resistance and beyond. Cancer Res 74: 3-7, 2014.

86 Yao ES, Zhang H, Chen YY, Lee B, Chew K, Moore D and Park C: Increased $\beta 1$ integrin is associated with decreased survival in invasive breast cancer. Cancer Res 67: 659-664, 2007.

87 dos Santos PB, Zanetti JS, Ribeiro-Silva A and Beltrão EIC: $\beta 1$ Integrin predicts survival in breast cancer: a clinicopathological and immunohistochemical study. Diag Pathol 7: 104, 2012.

88 Ali HR, Dawson SJ, Blows FM, Provenzano E, Pharoah PD and Caldas C: Cancer stem cell markers in breast cancer: pathological, clinical and prognostic significance. Breast Cancer Res 13: R118, 2011.

89 Ye F, Qiu Y, Li L, Yang L, Cheng F, Zhang H, Wei B, Zhang $\mathrm{Z}$, Sun $\mathrm{L}$ and $\mathrm{Bu} \mathrm{H}$ : The presence of EpCAM-/CD49f+ cells in breast cancer is associated with a poor clinical outcome. J Breast Cancer 18: 242-248, 2015.

90 Eirew P, Stingl J, Raouf A, Turasshvili G, Aparicio S, Emerman JT and Eaves CJ: A method for quantifying normal human mammary epithelial stem cells with in vivo regenerative ability. Nat Med 14: 1384-1389, 2008.

91 Lim E, Vaillant F, Wu D, Forrest NC, Pal B, Hart AH, AsselinLabat ML, Gyorki DE, Ward T, Partanen A, Feleppa F, 
Huschtscha LI, Thorne HJ, KconFab, Fox SB, Yan M, French JD, Brown MA, Smyth GK, Visvader JE and Lindeman GF: Aberrant luminal progenitors as the candidate target population for basal tumor development in BRCA1 mutation carriers, Nat Med 15: 907-913, 2009.

92 Hale JS, Li M and Lathia JD: The malignant social network: cell-cell adhesion and communication in cancer stem cells. Cell Adh Mig 6: 346-355, 2012.

93 Cariati M, Naderi A, Brown JP, Smalley MJ, Pinder SE, Caldas $\mathrm{C}$ and Purushottam AD: Alpha-6 integrin is necessary for the tumourigenicity of a stem cell-like subpopulation within the MCF7 breast cancer cell line. Int J Cancer 122: 298-304, 2008.

94 Zawistowski JS, Nakamura K, Parker JS, Granjer DA, Golitz BT, Johnson GL: MicroRNA 9-3p targets $\beta 1$ integrin to sensitize claudin-low breast cancer cells to MEK inhibition. Mol Cell Biol 33: 2260-2274, 2013.

95 Ivanova I, Vermeulen JF, Ercan C, Houthuijzen JM, Saig SA, Vlug EJ, van der Wall E, van Diest PJ, Vooijs M and Derksen PWK: FER kinase promotes breast cancer metastasis by regulating $\alpha 6$-and $\beta 1$-integrin-dependent cell adhesion and anoikis resistance. Oncogene 32: 5582-5592, 2013.

96 Hernandez L, Wilkerson PM, Lambros MB, Campion-Flora A, Rodrigues DN, Gauthier A, Cabral C, Pawar V, Mackay A, A’Hern R, Marchió C, Palacios J, Natrajan R, Weigelt B and Reis-Filho JS: Genomic and mutational profiling of ductal carcinomas in situ and matched adjacent invasive breast cancers reveals intra-tumour genetic heterogeneity and clonal selection. J Pathol 227: 42-52, 2012.

97 Martelotto LG, Baslan T, Kendall J, Geyer FC, Burke KA, Spraggon L, Piscuoglio S, Chadalavada K, Nanjangud G, Ng CKY, Moody P, D'Italia S, Rodgers L, Cox H, Paula ADC, Stepansky A, Schizas M, Wen HY, King TA, Norton L, Weigelt B, Hicks JB and Reis-Filho JS: Whole-genome single-cell copy number profiling from formalin-fixed, paraffin-embedded samples. Nat Med 23: 376-385, 2017.

98 Reis-Filho JS: Next-generation sequencing. Breast Cancer Res 11: S12, 2009.

99 Stephens PJ, Tarpey PS, Davies H, Van Loo P, Greenman C, Wedge DC, Nik-Zainal S, Martin S, Varela I, Bignell GR, Yates LR, Papaemmanuil E, Beare D, Butler A, Cheverton A, Gamble J, Hinton J, Jia M, Jayakumar A, Jones D, Latimer C, Wai Lau K, McLaren S, McBride DJ, Menzies A and Strattton MR: The landscape of cancer genes and mutational processes in breast cancer. Nature 486: 400-404, 2012.

100 Klevebring D, Rosin G, Ma R, Lindberg J, Czene K, Kere J, Fredriksson I, Bergh J and Hartman J: Sequencing of breast cancer stem cell populations indicates a dynamic conversion between differentiation states in vivo. Breast Cancer Res 16: R72, 2014.
101 Paula ADC, Leitão C, Marques O, Rosa AM, Santos AH, Rêma A, Faria MDF, Rocha A, Costa JL, Lima M and Lopes C: Molecular characterization of $\mathrm{CD} 44^{+} / \mathrm{CD} 24^{-} / \mathrm{Ck}^{+} / \mathrm{CD} 45^{-}$cells in benign and malignant breast lesions, Virchows Arch 470: 311-312, 2017.

102 Harrison H, Farnie G, Howell SJ, Rock RE, Stylianou S, Brennan KR, Brundred NJ and Clarke RB: Regulation of breast cancer stem cell activity by signaling through the NOTCH4 receptor. Cancer Res 70: 709-718, 2010.

103 Pham PV, Phan NLC, Nguyen NT, Truong NH, Duong TT, Le DV, Truong KD and Phan NK: Differentiation of breast cancer stem cells by knockdown of CD44: promising differentiation therapy. J Trans Med 9: 209, 2011.

104 Knudsen ES and Witkiewicz A: EZH2 and ALDH1 expression in ductal carcinoma in situ: complex association with recurrence and progression to invasive breast cancer. Cell Cycle 12: 2042-2050, 2013.

105 Korkaya H, Paulson A, Charafe-Jauffret E, Ginestier C, Brown M, Dutcher J, Clouthier SG and Whicha MS: Regulation of mammary stem/progenitor cells by PTEN/AKT/ $\beta$-catenin signaling. PLoS Biol 7: e1000121, 2009.

106 Raha D, Wilson TR, Peng J, Peterson D, Yue P, Evangelista M, Wilson C, Merchant M and Settleman J: The cancer stem cell marker aldehyde dehydrogenase is required to maintain a drugtolerant tumor cell subpopulation. Cancer Res 74: 3579-3590, 2014.

107 Ahmed KM, Zhang $\mathrm{H}$ and Park CC: NF-kB regulates radioresistance mediated by $\beta 1$-integrin in three-dimensional culture of breast cancer cells. Cancer Res 73: 3737-3748, 2013.

108 Narita T, Kimura N, Sato M, Matsuura N and Kannagi R: Altered expression of integrins in adriamycin-resistant human breast cancer cells. Anticancer Res 18: 257-262, 1997.

109 Fawzi A and Vuori K: Integrin signaling inhibits paclitaxelinduced apoptosis in breast cancer cells. Oncogene 20: 49955004, 2001.

110 Nisticò P, Di Modugno F, Spada S and Bissel MJ: $\beta 1$ and $\beta 4$ integrins: from breast development to clinical practice. Breast Cancer Res 16: 10-1186, 2014.
Received February 25, 2017

Revised March 22, 2017

Accepted March 24, 2017 